\title{
An Examination of Administrators' Nonrevenue, Olympic Program Values within NCAA Athletic Departments
}

\author{
Coyte Gene Cooper, Erianne A. Weight \\ University of North Carolina-Chapel Hill
}

\begin{abstract}
The presence of the arms race in intercollegiate athletics has led to extensive spending on major, revenue-producing sports (Knight Commission, 2004). Despite the fact that only a handful of men's basketball and football programs produce profits (NCAA, 2009), administrators continue to embrace a commercial model that has coincided with the elimination of nonrevenue, Olympic sports in National Collegiate Athletic Association (NCAA) athletic departments. With this in mind, the purpose of the study was to gain an understanding of the nonrevenue, Olympic program elements that were most highly valued by NCAA Division I, II, and III athletic administrators $(\mathrm{N}=435)$ to facilitate an effort to develop strategic measures to counter program discontinuation. Despite small differences in divisional responses, the results supported the existence of institutional isomorphism when unified program values (e.g., academics, conduct, community involvement) were consistent across all NCAA divisions.
\end{abstract}

The arms race of intercollegiate athletic expenditures (Knight Commission, 2004) continues to grow as conference realignments, multibillion dollar television agreements, and superstar amateur athletes dominate the headlines (Zagier, 2010). Despite a reality revealing that only a handful of programs produce profits (NCAA, 2009), this empire of commercialism stands as the most visible product of the administrative reward system in intercollegiate athletics. While the empire has risen, many sport traditions have fallen as "nonrevenue," Olympic sport ${ }^{1}$ programs have been eliminated. In fact, between 1988 and 2008, there were a total of 2,606 teams that were dropped, with a net loss of 287 men's teams at the Division I level (NCAA, 2010). As the recession continues, a new wave of sport cuts has occurred (DeSchriver, 2009; Steinbach, 2007), leaving many Olympic sport stakeholders searching for proactive methods to fortify their programs.

\section{Significance of Research}

As previously mentioned, the purpose of this study was to gain an understanding of the nonrevenue, Olympic program elements that were most highly valued by

The authors are with Department of Exercise and Sport Sciences, University of North Carolina - Chapel Hill, NC. 
NCAA Division I, II, and III athletic administrators to facilitate an effort to develop strategic measures to counter program discontinuation. While developing a greater understanding of administrator values will not in itself curb the discontinuation trend, the data provides insight into organizational standards that can help guide coaches and decision makers in resource allocation decisions in the Olympic sport institutional sphere. In essence, a better understanding of the facets of nonrevenue sports deemed most important to administrators can help in an effort to develop strategic measures to best avoid program elimination. It is through this understanding that coaches will have the ability to act as the CEO's of their program when they highlight critical areas of emphasis. In addition, this research can facilitate fortification through a deeper understanding of the institutional structures that house nonrevenue sports and education of key stakeholders in the Olympic sport institutional sphere. The theoretical framework will be discussed in the following section to help guide the research.

\section{Theoretical Framework}

Institutional theory postulates that organizations, like individuals, seek approval or legitimacy from their peers. As such, organizations tend to behave in ways that are consistent with the actions and orientations of the organizations within their institutional sphere. An important element of institutional theory proposes that organizations within the same social system are influenced by one another and tend to imitate one another (DiMaggio\& Powell, 1983, 1991; Scott, 2001, Scott \& Meyer, 1994). University athletic departments within the same conference, for example, are likely to espouse similar core values, offer the same kinds of services, support a similar organizational structure, and prioritize budgets in a similar fashion (Chelladurai, 2005). The process of organizations becoming similar to one another is called institutional isomorphism (DiMaggio\& Powell, 1983).

As a sub-element to institutional theory, DiMaggio \& Powell (1983) suggested three forces that may lead to isomorphism - or institutions resembling one another. One of these forces that is particularly critical to the theoretical foundation of this study is normative isomorphism. The basic premise of normative isomorphism is the idea that all organizations act similarly due to the values and processes adopted by the decision makers. These decision makers, most likely, have been trained and educated within organizations or universities who use and promote analogous methods and strategies. Many athletic directors, for instance, may have been educated utilizing similar text books, curricula, and career paths through the NCAA system. These values and beliefs that have been engrained in them throughout their training will be reflected in the structures and processes these administrators institute within their respective organizations.

As we explore the value of Olympic sports through the eyes of NCAA athletic administrators, this theory provides a very fitting theoretical foundation. Based on previous research it is clear that within intercollegiate athletics, there is an evident dualism in value systems. On one side resides the stated purpose of intercollegiate athletics "to integrate intercollegiate athletics into higher education so that the educational experience of the student-athlete is paramount" (NCAA, 2010). An often-opposing value system, however, is frequently present with the arms race of 
expenditures toward the never-ending battle for supremacy, national exposure, and financial rewards (Knight Commission on Intercollegiate Athletics [KCIA], 2010).

For most teams at most institutions, these roles can be reconciled. But in highprofile sports, tensions often surface between the core mission of universities and commercial values. These tensions have grown significantly over the past two decades. The pursuit of television contracts and slots in football bowl games, together with the quest to win championship tournaments in basketball, have had a destabilizing influence on athletics programs. Among other worrisome developments, the intensely competitive environment at the top levels of college sports has prompted four rounds of realignment among athletic conferences since 1994; a bidding war for prominent coaches; and escalating expenses across the board (KCIA, 2010, p.3).

Theoretically, education should be the primary purpose of intercollegiate athletics (NCAA, 2010). The mission statements of university athletic departments throughout the country purport the emphasis on the student-athlete. Those who have been trained within the functioning walls of many athletic departments, however, have learned that career success and advancement in intercollegiate athletics is largely dependent on the success of the football and basketball team in addition to the fundraising that is accomplished (Zimbalist, 1999). Each athletic director has been trained, educated, and advanced through this same system with these often conflicting value systems. Institutional theory suggests that these administrators would attempt to seek legitimacy and approval from the administrators within their institutional sphere, institutional isomorphism would suggest the institutions to be similar to one another in terms of their value systems, and normative isomorphism suggests that these similarities are largely due to the value system of the decision makers. With the dualism present at all levels of this theoretical foundation, it is difficult to ascertain how this dualism fits into the overall picture, and specifically how administrators might value Olympic sports.

Athletic directors may strive to espouse the core educational values through the Olympic sports that often are less tainted by the pull of commercialism and corporate model mentality that drives much of the alternative value systems often prevalent in revenue producing sports. Within the big time sports, these core values, while ever-present, seem to often get lost in the search for championships and the national exposure success can bring. Although there is often a pull toward commercialization, there is also a pull toward legitimacy and approval from their university environments. In an era of program discontinuation, stretched budgets, and talk of reform, research into the true value of Olympic sport through the perspective of those who hold the reigns within intercollegiate athletic departments is critical. Before discussing this research initiative, the previous literature focusing on program elimination in college athletics will be examined to guide the study.

\section{Review of Related Literature}

\section{Sport Discontinuation}

In today's intercollegiate athletic environment, administrators have the unique challenge of balancing university values while attempting to maximize the revenues 
realized by their department. In an effort to maintain financial sustainability, several athletic directors have publically stated that the elimination of men's nonrevenue programs is the only way to balance their athletic budgets (Arizona State, 2008; Steinbach, 2007). Despite this claim, Marburger and Hogshead-Makar (2003) have instead argued that the trend to eliminate programs is driven primarily by profit-motivated athletic programs and not by tight budgets. Further as explained by Ridpath, Yiamouyiannis, Lawrence, and Galles (2008), the loss of nonrevenue teams can "arguably can be found in out-of-control and unfair economics in bigtime college athletic programs" and the "reallocation of money from some men's sports (such as wrestling) to other men's sports (such as football, basketball, and even baseball)" (p. 278). While men's Olympic sport programs have suffered most severely in program discontinuations (National Collegiate Athletic Association, 2008) recent trends support the notion that even women's programs are not safe in today's increasingly competitive intercollegiate athletic environment. For example, in 2006, James Madison University stated monetary constraints from Title IX when making the decision to eliminate seven men's and three women's Olympic sport teams (Dopirak, 2006). Regardless of the reasoning for program eliminations, with rising costs in men's basketball and football (Marburger \& Hoghead-Makar, 2003), coupled with state budget deficits and higher education cut-backs which may reduce the amount of institutional support available to sustain unprofitable athletic programs (Brady, 2009), it is clear that nonrevenue sport teams will be facing declining financial support in future generations (James \& Ross, 2004).

To further shed light onto the justifications for program eliminations, several scholars have surveyed athletic directors to understand the reasons why programs are cut (Gray \& Pelzer, 1995; Williamson, 1983). In a pioneer study on nonrevenue program eliminations, Williamson (1983) surveyed athletic directors and concluded that the discontinuations of sport programs were most influenced by the following factors: (1) lack of student interest, (2) high cost, (3) lack of recruitable prospects, and (4) lack of spectator appeal. Similarly, in a follow-up study, Gray and Pelzer (1995) demonstrated overlapping trends when reporting that the following factors had the most significant influence on athletic director's decisions to eliminate nonrevenue programs: (1) conference alignment, (2) shifting resources, (3) inconvenient travel, (4) cost, (5) lack of spectators, and (6) lack of student interest.

In addition to the previous studies on program discontinuations, several scholars have voiced their opinions on the primary reasons for nonrevenue program eliminations (Carroll \& Humphreys, 2000; Leland \& Peters, 2003). In an effort to understand these program eliminations, Carroll and Humphries used a nonprofit economic behavior model to explore the effects that Title IX and gender equity regulations have on athletic administrators within university setting. With a model predicting a decrease in the number of sport teams and a net decrease in the number of men's teams, the authors suggested that size and prestige of the athletic program served as "important factors affecting the probability that men's sports teams were eliminated to comply with regulation" (2000, p. 359).

As the trend to eliminate Olympic sport teams continued, the United States General Accounting Office (USGAO) conducted a study examining the differing strategies used by universities to avoid program discontinuation. Within the time period of 1992-2000, the 693 schools that added one or more intercollegiate athletic teams without discontinuing a team "pursued creative strategies to build athletic 
programs without discontinuing teams" (2001, p.25). These "creative strategies" included several methods of raising revenue and cutting costs. Fundraising efforts included seeking donations, renting athletic facilities, providing overflow parking for city events, and hosting events. Cost containment strategies included recruiting via telephone, replacing full-time faculty positions with a coach, limiting the size of the football roster, and limiting team travel, among other strategies (GAO, 2001). This "creative strategy" conclusion serves as an important source of founding evidence to support the premise that there are ways to combat program elimination.

Weight (2009) explored the potential role of a nonrevenue coach pursuing creative strategies in an effort to help enhance the sustainability of NCAA wrestling programs. In this study researching Division I Athletic Directors and Division I Wrestling Coaches, athletic directors reported that coaches can enhance their program's chance of vitality through complementary entre-lationship promotion. A program can be strengthened by complementary coaches led by an entrepreneur who continually strives to build indispensable relationships with donors, athletic department administrators, prominent figures, \& alumni; is active in fundraising; is promoting their sport; and is promoting the program's public perception. The study concludes that if a coach can build significant demand for his/her program, the supply will be fortified and considerably less likely to get cut.

Building on the concept that a coach can have a pivotal role in the effort to sustain nonrevenue sports, Weight and Cooper (2011) studied athletic directors and wrestling head coaches of Football Bowl Subdivision universities who have sponsored wrestling within the past ten years to explore perceptions regarding the criteria used in program-termination decisions. Findings suggest that athletic directors use budget shortages and the financial strain of the program as primary discontinuation criteria followed by gender equity implications, success on the mat, and regional sport popularity. In contrast, the coaches indicated that gender equity, regional sport popularity, donor support, and athletes actions off the mat were the primary reasons for program eliminations. Thus, the results illustrate that athletic directors and coaches have significantly different perceptions about the reasons why nonrevenue programs such as men's wrestling are eliminated. Given the potentially significant role a coach can have in the shaping of program priorities and value systems, it is troubling to find such a disparity between athletic director criteria and coach beliefs.

While the previous research has provided a sound foundation for understanding program eliminations, there are some limitations in the literature that need to be addressed. First, the emphasis on the reasons why programs were eliminated in the past is a retroactive approach to sustainability. Thus, to improve chances of nonrevenue sport program sustainability, there must be a focus on the nonrevenue program values that are most important to administrators in today's intercollegiate athletic environment. With this understanding, coaches have the opportunity to act as the CEO of their programs as they highlight program areas that are valued in their respective athletic departments. Based on this assessment, the following research questions were created to guide the study:

[RQ 1] What are the nonrevenue, Olympic program values that are most important to NCAA [1A, 1B, 1C] administrators within their coinciding athletic departments? 


\section{[1A] Division I \\ [1B] Division II \\ [1C] Division III}

[RQ 2] Are there variations in the nonrevenue, Olympic program values that are most important to NCAA administrators when focusing on the divisional affiliation (Division I, Division II, Division III) of the athletic department being examined?

\section{Method}

\section{Survey Instrument}

For the purpose of this study, the NCAA Program Value scale was developed and used. The 17-item instrument was patterned after those used in inquiries measuring organizational value systems (Amos \& Weathington, 2008; De Clercq, Fontaine, $\&$ Anseel, 2008). However, the specific target of NCAA program values had not been examined directly or indirectly in previous research. Thus, the construct validity of the instrument was addressed utilizing a panel of experts including four intercollegiate athletic administrators, two professors, and an expert in research and survey design. This panel was consulted to review and modify the instrument's content. After several rounds of revisions, the panel unanimously supported the instrument validity.

Based on the consultation with the panel of experts, the decision was made to include an additional background question to gain an understanding of the NCAA athletic departments participating in the research (e.g., Divisional affiliation, conference affiliation). In addition, the panel agreed on the inclusion of 11 specific Olympic program value elements in the survey instrument (see Table 1). For the questions within this section, a 6-point Likert type scale $(1=$ strongly disagree; 6 = strongly agree) was used to examine administrator's responses to the program values. Similarly, three open-ended questions were included to allow administrators to expand on their perceptions of the most important nonrevenue, Olympic program elements.

\section{Sample}

The instrument was distributed via e-mail to the entire population of NCAA Division I, II, and III athletic departments (1,055 institutions). Through the use of athletic department website staff directories, the head Athletic Directors were identified as the primary contact for the e-mail invitations. However, the two highest-ranking senior administrators were also copied on the invitation to maximize the return rate of the survey. As a precaution to avoid redundancy in athletic department responses, the head athletic director was asked to have one administrator (with most appropriate credentials) respond to the research. Following a one month lapse of the invitations, a total of $435(41.2 \%)$ NCAA athletic departments responded to the survey (Division I $[n=162 ; 48.4 \%]$; Division II $[n=124 ; 43.1 \%]$; Division III $[n=149 ; 34.5 \%])$. 


\section{Table 1 Cumulative NCAA Division I, II, and III Administrator's Responses to Olympic Program Values}

\begin{tabular}{lcc}
\hline Olympic Program Values & $\boldsymbol{M}$ & $\mathbf{S D}$ \\
\hline Conduct (Competition) & $* 5.77$ & .601 \\
Proper behavior exhibited by coaches/student-athletes during competition. & .658 \\
Academic Achievement & $* 5.69$ & .652 \\
High levels of individual and team success in the classroom. \\
Conduct (Social) & $* 5.69$ & .959 \\
Proper behavior exhibited by coaches/student-athletes outside of competition. \\
Personal Relationships & $* 5.20$ & .940 \\
Strong relationships between administrators and members of coaching staff. \\
Community Involvement & $* 5.09$ & .964 \\
Strong team presence in local community service initiatives. \\
Athletic Success & $* 5.08$ & 1.275 \\
High levels of individual/team success in sport competition. \\
Fundraising & $* 4.41$ & 1.511 \\
Development of external funds to supplement team's operating budget. \\
Enrollment & $* 4.30$ & 1.549 \\
Increase in university enrollment from student-athlete participation on team. \\
Fan Support & 4.00 & 1.160 \\
Strong team support by fans in surrounding geographical region. \\
Program Cost & 3.84 & 1.305 \\
Low cost to fund the annual operating budget of sport team. \\
Revenue Production & 3.02 & \\
Development of positive revenue streams at team athletic competitions. \\
\hline
\end{tabular}

Note. The scale ranged from Strongly Disagree (1) to Strongly Agree (6)

$* p<.001(\mu \geq 5)$

\section{Data Analysis}

Descriptive statistics were generated for scale items and a T-test was conducted for each item to determine significance of the sample mean relative to the scale (see Table 2). In addition, the authors used analysis of variance to examine the impact of division relative to the administrator values placed upon the different items within the NCAA Program Value Scale. Due to the large sample size, effect size calculations using Cohen's d were related to all significant findings.

\section{Results}

Descriptive statistics identified the "cumulative" nonrevenue, Olympic program values that NCAA administrators (Division I, II, and III combined) rated as having 
Table 2 NCAA Administrator's Perceptions of Nonrevenue, Olympic Program Values (Divisional)

\begin{tabular}{lcccccc}
\hline & \multicolumn{2}{c}{ NCAA Division } & \multicolumn{2}{c}{ NCAA Division } \\
II & & \multicolumn{2}{c}{$\begin{array}{c}\text { NCAA Division } \\
\text { III }\end{array}$} \\
\hline Program Values & $\boldsymbol{M}$ & SD & $\boldsymbol{M}$ & SD & $\boldsymbol{M}$ & SD \\
Conduct (Competition) & $5.80^{*}$ & .650 & $5.72^{*}$ & .644 & $5.79^{*}$ & .496 \\
Academic Achievement & $5.73^{*}$ & .667 & $5.68^{*}$ & .659 & $5.65^{*}$ & .648 \\
Conduct (Social) & $5.75^{*}$ & .659 & $5.70^{*}$ & .686 & $5.62^{*}$ & .586 \\
Personal Relationships & $5.19^{*}$ & 1.011 & $5.18^{*}$ & .902 & $5.24^{*}$ & .953 \\
Community & $5.12^{*}$ & .896 & $5.22^{*}$ & .916 & $4.96^{*}$ & .992 \\
Involvement & & & & & & \\
Athletic Success & $5.30^{*}$ & .869 & $5.05^{*}$ & .936 & $4.88^{*}$ & 1.039 \\
Fundraising & $4.57^{*}$ & 1.216 & $4.59^{*}$ & 1.211 & 4.09 & 1.336 \\
Enrollment & 3.69 & 1.506 & $4.81^{*}$ & 1.327 & $4.56^{*}$ & 1.433 \\
Fan Support & $4.30^{*}$ & .884 & 4.08 & 1.177 & 3.63 & 1.307 \\
Program Cost & 3.67 & 1.387 & 3.98 & 1.224 & 3.92 & 1.263 \\
Revenue Production & 3.34 & 1.496 & 3.20 & 1.557 & 2.52 & 1.482 \\
\hline
\end{tabular}

Note. The scale ranged from Strongly Disagree (1) to Strongly Agree (6).

$* p<.01(\mu \geq 4)$

the highest level of importance within their coinciding athletic departments. In addition to the means and standard deviations, the research used a one-sample T-Test $(\mu \geq 4)$ to examine each of the program values included in the research. As illustrated in Table 1, there were eight program values that were significantly higher than 4, "agreement," at the $p=.001$ level: conduct (competition) $[t(429)=61.22, p$ $<.001]$, academic achievement $[t(431)=53.40, p<.001]$, conduct (social) $[t(433)$ $=54.22, p<.001]$, personal relationships $[t(432)=26.05, p<.001]$, community involvement $[t(434)=24.29, p<.001]$, athletic success $[t(434)=23.44, p<.001]$, fundraising $[t(428)=6.70, p<.001]$, and enrollment $[t(430)=4.18, p<.001]$. The remaining results within each division are discussed in the following sections.

\section{Division I Olympic Program Values}

In response to Research Question 1, the program values were examined based on the affiliation of the athletic department to determine the elements that were most important at the Division I, II, and III levels (see Table 2). When focusing on the Division I administrator's responses, the data illustrated that there were eight Olympic program values that were rated as statistically significant $(\mu \geq 4)$ in the research: conduct (competition) $[t(160)=35.15, p<.001]$, conduct (social) $[t(161)$ $=32.89, p<.001]$, academic achievement $[t(161)=33.11, p<.001]$, personal relationships $[t(161)=14.97, p<.001]$, community involvement $[t(161)=15.94$, $p<.001]$, athletic success $[t(161)=18.97, p<.001]$, fundraising $[t(159)=5.92, p$ $<.001]$, and fan support $[t(161)=4.27, p<.001]$. 


\section{Division II Olympic Program Values}

Similar to the Division I level, the following six program values were rated the highest at the Division II level: conduct (competition) $[t(122)=29.68, p<.001]$, conduct (social) $[t(123)=27.60, p<.001]$, academic achievement $[t(121)=26.17$, $p<.001]$, community involvement $[t(123)=14.81, p<.001]$, personal relationships $[t(123)=14.53, p<.001]$, athletic success $[t(123)=12.48, p<.001]$. In addition, when focusing on the remaining Olympic program values, there were two other elements that were rated as statistically significant by NCAA Division II administrators: fundraising $[t(121)=5.38, p<.001]$, and enrollment $[t(122)=6.78, p<.001]$.

\section{Division III Olympic Program Values}

Similar to Division I and Division II, the data supported the notion that Division III administrators had the following six program values rated as the most important within their athletic department: conduct (competition) $[t(144)=43.31, p<.001]$, academic achievement $[t(147)=30.95, p<.001]$, conduct (social) $[t(147)=33.78$, $p<.001]$, personal relationships $[t(146)=15.75, p<.001]$, community involvement $[t(148)=11.81, p<.001]$, athletic success $[t(148)=10.34, p<.001]$. Further, the enrollment program value $[t(145)=4.73, p<.001]$ was rated as an important nonrevenue program element for Division III athletic departments.

\section{Variations in Divisional Responses}

In response to Research Question 2, the data analyses used an analysis of variance to determine whether there were statistically significant differences in NCAA (Division I, II, and III) administrator's responses to nonrevenue, Olympic program values. As shown in Table 3, the results illustrated that divisional affiliation had a significant influence on the following program value elements: athletics $[\mathrm{F}(2,432)$ $=7.61, p<.01]$, enrollment $[\mathrm{F}(2,431)=25.26, p<.01]$, fan support $[\mathrm{F}(2,434)=$ $13.89, p<.01]$, fundraising $[\mathrm{F}(2,429)=7.13, p<.01]$, and revenue production $[\mathrm{F}$ $(2,431)=12.51, p<.01]$. When focusing on the difference within these groups, the data demonstrated that athletics, fan support, and fundraising were significantly more important to Division I administrators than Division III administrators. In contrast, the results also showed that Division II and Division III administrators placed a significantly higher value on enrollment than Division I administrators as these institutions often use athletics to attract students who pay their own tuition, this revenue stream and the numbers generated through these sports, therefore, represent a value to the administrators.

\section{Open-Ended Responses}

The examination of open-ended responses reinforced the previous data as administrators regularly listed conduct and academics as two of their top nonrevenue, Olympic sport program values. In addition, the information also indicated that student-athlete experience was an element that administrators value in these Olympic sport programs. Similarly, within this structure, administrators stated that the development of student-athletes (character, integrity) was a priority for their 
Table 3 Variations in NCAA Division I, II, and III Administrator's Perceptions of Program

\begin{tabular}{|c|c|c|c|c|}
\hline \multicolumn{5}{|c|}{ Values (Analysis of Variance) } \\
\hline Factor $(N=435)$ & $\mathbf{F}$ & $p$ & Mean Difference & Cohen's d \\
\hline Athletics & $7.605^{*}$ & .001 & & \\
\hline Division I v. Division III & & .000 & $.417 *$ & .44 \\
\hline Academics & .677 & .509 & & \\
\hline Community Involvement & 2.697 & .069 & & \\
\hline Conduct (Competition) & .668 & .513 & & \\
\hline Conduct (Social) & 1.426 & .241 & & \\
\hline Enrollment & $25.262 *$ & .000 & & \\
\hline Division I v. Division II & & .000 & $-1.530 *$ & .79 \\
\hline Division I v. Division III & & .000 & $-1.261 *$ & .59 \\
\hline Fan Support & $13.897 *$ & .000 & & \\
\hline Division I v. Division III & & .000 & $.665^{*}$ & .21 \\
\hline Division II v. Division III & & .003 & $.451^{*}$ & .60 \\
\hline Fundraising & $7.134 *$ & .001 & & \\
\hline Division I v. Division III & & .003 & $.474 *$ & .38 \\
\hline Division II v. Division III & & .004 & $.495 *$ & .39 \\
\hline Personal Relationships & .169 & .845 & & \\
\hline Program Costs & 2.468 & .086 & & \\
\hline Revenue Production & $12.507 *$ & .000 & & \\
\hline Division I v. Division III & & .000 & $.818 *$ & .55 \\
\hline Division II v. Division III & & .001 & $.679 *$ & .45 \\
\hline
\end{tabular}

$* \mathrm{p}<.01$

athletic departments. Finally, the open-ended responses indicated that administrators also placed a priority on the fit of the sport program into the larger department and academic institution.

\section{Discussion}

\section{A Divided System}

The primary underpinning of institutional theory is that an organization tends to emulate the other organizations in the sphere of organizational association (DiMaggio \& Powell, 1983).

This implementation has been seen in action within the arms race in intercollegiate athletics, and it is seen in the value placed within nonrevenue sports. The small standard deviations and clear agreement the athletic directors demonstrated in highly valuing Olympic sport academics supports the theory of institutional isomorphism. In an era where the educational mission of intercollegiate athletics is in question 
(Coalition on Intercollegiate Athletics, 2005; 2007), many proclaim the educational mission to be lost. Our findings reveal the educational values within intercollegiate athletics to be quite strong. What we see, however, is an athletic organism that has morphed into a divided system. Each school mimicking one another in the arms race of expenditures in their revenue sports (KCIA, 2010), while maintaining core values in the Olympic sports. What our data support is institutional isomorphism with divided purposes within athletic departments.

Why did the athletic administrators respond unquestionably that academics are of maximal importance? Normative isomporphism postulates that the similarity between organizations within an institutional system is largely due to the thoughts and values of the administrators. These administrators were most likely trained and rewarded similarly throughout their educational and professional journey through the NCAA system with the often conflicting value systems including education, amateurism, and commercial success. The financial pull is not so evident within the Olympic sports, so these programs may present relief to administrators striving to align the stated purpose and actual purpose of their athletic departments. The pure values of intercollegiate athletics can be unfalteringly focused upon within these programs. If nonrevenue coaches are aware of this divide between the push for academic institutional values, and the pull of the arms race, coaches can strive to facilitate the assimilation of university value systems with athletic department value systems, and therefore strive to uphold the true mission of intercollegiate athletics - through academic success.

In addition to the academic values, the research also demonstrated three other unified program elements that support the notion of institutional isomorphism among NCAA athletic departments. When focusing on the divisional responses, the high mean values and small standard deviations within both forms of conduct (competition and social) indicates that administrators at all levels value the image that nonrevenue, Olympic sport teams portray in the surrounding community. Similar to the academic values, the emphasis on solid conduct by coaches and student-athletes represent program elements that line up with departmental and university value systems.

While the research seems to support the notion that administrators embrace solid core principles, it must also be mentioned that athletic success was rated as an important Olympic program element at all NCAA levels. However, with an indicated lack of emphasis on financial objectives, administrators seem to see Olympic sports as avenues to embrace the competitive nature of intercollegiate sport. It is important to note that this does not necessarily contradict the previous program elements that emphasize the true value of intercollegiate sport. Instead, with a lack of solid financial return on investment (ROI) in these nonrevenue, Olympic sports, the data seems to support the notion that administrators embrace the educational lessons that are offered to student-athletes through competitive sport. Again, with a unified agreement across all NCAA divisions, this result reinforces the existence of institutional isomorphism within athletic departments at the intercollegiate level.

\section{Practical Implications}

With the previous theoretical assumptions in mind, it is important to mention the practical implications from the research for administrators and coaches. From a broad perspective, the existence of a "unified" set of NCAA program values (e.g., 
academics, conduct, community involvement) gives coaches a sound understanding of the program elements that are consistently being emphasized within individual athletic departments. Similarly, it provides nonrevenue, Olympic advocate groups (e.g., National Wrestling Coaches Association [NWCA]) with the information necessary to create educational programs designed to enhance the sustainability of programs across the United States. Ultimately, this provides coaches with an opportunity to maximize their program efficiency by focusing on the elements that are most valued by administrators.

As nonrevenue, Olympic advocate groups and coaches move forward, it is important that they realize that value systems exist within their NCAA athletic department. However, our research indicates that this institutional value system extends well beyond athletic success for these programs. Instead, there are a variety of critical program values that Olympic coaches must embrace if they are going to enhance their chances for sustainability within their athletic department. Thus, with this in mind, it would be wise for coaches to invest in broad-based initiatives that allow them to maximize their "fit" within their coinciding athletic departments. More importantly, the understanding of these program values offers the opportunity to highlight elements that will minimize their chances of program elimination in future years.

As discussed in the results section, there were a few small variations in program values when focusing on the divisional affiliation of athletic departments. Primarily, these differences were present outside of the program elements that were rated highest by administrators. With this in mind, these differences are important to mention because they represent small variations in institutional values at the different NCAA levels. For example, the enrollment program element was rated higher at Division II and III levels than at the Division I level. When focusing on the mean values within this program value, the results indicate that Division II and Division III coaches may want to emphasize this element when running their program. In contrast, it may not be worth Division I coaches time to invest in this particular area. The remaining results have the same practical implications for nonrevenue, Olympic coaches.

\section{Conclusions}

The examination of the nonrevenue, Olympic program values within the research reinforces the fact that institutional isomorphism exists among athletic departments at all NCAA levels. For advocate groups and coaches, this provides a unique opportunity to improve the positioning of their program by embracing the unified values exhibited in the research. However, with this in mind, there are some limitations in the study that should be mentioned. First, with an emphasis on athletic director perceptions, the research did not identify the program values that coaches feel are valued most within their athletic departments. Through this type of analysis, researchers could identify whether coaches understand the value systems that will allow them to enhance their sustainability in future years. In addition to providing a foundation to develop educational programs, a study of this nature could also help develop an understanding of the communication systems that exist in athletic departments. In addition, the research is also limited by the honesty of the administrators that participated in the online survey. 
Another limitation of the current research is that it focused on the divisional program values featured within nonrevenue, Olympic sports. With a segmented emphasis on conference program values, coaches could have a strengthened understanding on the elements most deserving of their limited time. Further, researchers could add depth to the literature by examining administrator's program values within "big time," revenue-producing sports. In addition, these areas of emphasis could provide additional data to support the concept of institutional isomorphism within NCAA athletic departments. Future studies should also focus on determining whether institutional isomorphism exists within other athletic environments.

\section{Note}

1. In intercollegiate athletic environments, the term "nonrevenue," Olympic refers to the sport programs in NCAA athletic departments that are not seen as capable of generating a profit. In general, this means all sport programs outside of men's basketball and men's football because there are programs within these sports that operate at a profit.

\section{References}

Amos, E., \& Weathington, B. (2008). An analysis of the relation between employee organization value congruence and employee attitudes. The Journal of Psychology, 142(6), $615-632$.

Arizona State University cites economics in reducing number of varsity sports. (2008, May 23). The Online Resource for the National Collegiate Athletic Association (NCAA). Retrieved May 18, 2008, from: http://www.ncaa.com/tennis-mens/article. aspx?id=239282.

Brady, E. (2009, February 18). Recession forces colleges to find ways to cut spending. USA Today. Retrieved March 2, 2009, from: http://www.usatoday.com/sports/college/200902-18-colleges-economy-cover_N.htm.

Carroll, K.A., \& Humphreys, B.R. (2000). Nonprofit decision making and social regulation: the intended and unintended consequences of Title IX. Journal of Economic Behavior \& Organization, 43(3), 59-376.

Coalition on Intercollegiate Athletics. (2005). Academic integrity in intercollegiate athletics: principles, rules, and best practices. Retrieved June 28, 2010 from: http://wfu.me/cms/ coia/index.php/Policy_Papers.

Coalition on Intercollegiate Athletics. (2007). Framing the future: reforming intercollegiate athletics. Retrieved June 28, 2010 from: http://wfu.me/cms/coia/index.php/ Policy_Papers.

Chelladurai, P. (2005). Managing organizations for sport and physical activity - a systems perspective (2nd ed.). Scottsdale, AZ: Holcomb Hathaway Publishers Inc.

De Clercq, S., Fontaine, J., \& Anseel, F. (2008). In search of a comprehensive value model for assessing supplementary person-organization fit. The Journal of Psychology, 142(3), 277-302.

Deschriver, T. (2009). Recession emerges as formidable foe for college sports. Phi Kappa Phi. Forum., 89(3), 14-16.

DiMaggio, P., \& Powell, W. (1983). The iron cage revisited: Institutional isomorphism and collective rationality in organizational fields. American Sociological Review, 48, 147-160.

DiMaggio, P., \& Powell, W. (1991). Introduction. In W. Powell \& P. DiMaggio (Eds.), The new institutionalism (pp. 1-38). Chicago: University of Chicago Press. 
Dopirak, D. (2006). USOC scolds JMU for cuts. The Daily News Record. Retrieved January 24, 2009, from: http://www.dnronline.com/sports_details.php?AID=6770\&CHID=3.

Gray, G.R., \& Pelzer, J.A. (1995). The Impact of Title IX on the Discontinuation of NCAA Division I Wrestling Programs. Journal of Legal Aspects of Sport, 5(2), 17-122.

James, J., \& Ross, S. (2004). Comparing sport consumer motivations across multiple sports. Sport Marketing Quarterly, 13(1), 17-25.

Knight Commission on Intercollegiate Athletics. (2004). Challenging the myth: A review of the links among college athletics success, student quality, and donations. Ithaca, NY: Frank, Robert H.

Knight Commission on Intercollegiate Athletics. (2010). Restoring the balance: dollars, values, and the future of college sport. Retrieved July 1, 2010 from: http://restoringbalance.knightcommission.org.

Leland, T., \& Peters, K. (2003). Unresolved Public Policy Issues. Marquette Sports Law Review, $14,1$.

Marburger, D. R., \& Hogshead-Makar, N. (2003). Is Title IX really to blame for the decline in intercollegiate men's non-revenue sports? Marquette Sport Law Review (14), Rev. 65.

National Collegiate Athletic Association. (2009). Revenues/expenses 2004-2008: NCAA revenues and expenses of NCAA Division I intercollegiate athletic programs report. Indianapolis, IN: Fulks, Daniel L.

National Collegiate Athletic Association. (2008). NCAA Sports Sponsorship and Participation Rates Report. Retrieved from: http://www.ncaapublications.com/productdownloads/ PR2010.pdf

Ridpath, B.D., Yiamouyiannis, A., Lawrence, H., \& Galles, K. (2008). Changing sides: The failure of the wrestling community's challenges to Title IX and new strategies for saving NCAA sport teams. Journal of Intercollegiate Sports, 1(2), 255-283.

Scott, W.R. (2001). Institutions and organizations. Thousand Oaks, CA: Sage.

Scott, R., \& Meyer, J. (1994). Institutional environments and organizations: Structural complexity and individualism. Thousand Oaks, CA: Sage.

Steinbach, P. (2007). Pinned hopes. Athletic Business. Retrieved May 18, 2008, from: http:// athleticbusiness.com/articles/article. aspx ?articleid=1624\&zoneid $=28$.

U.S. General Accounting Office. (2001). Intercollegiate athletics: four year college's experience adding and discontinuing teams. March 2001.

Weight, E.A. (2009). The role of the entrepreneurial coach: non-revenue sport survival within big-time intercollegiate athletics. International Journal of Sport Management., 10, 1-15.

Weight, E., \& Cooper, C.G. (2011). Bridging the gap: Athletic director answers and coach beliefs regarding nonrevenue program discontinuation decisions. Journal of Sport Administration \& Supervision, 3(1), 61-73.

Williamson, S.C. (1983). The ranking of reasons for discontinuing intercollegiate athletic sports as determined by athletic directors at institutions which have discontinued sports. (Doctoral dissertation, University of Northern Colorado, 1983). University Microfilms International.

Zagier, A.S. (2010, June 17). Reformers blast runaway spending in college sports. The Associated Press. Retrieved June 17, 2010 from: http://www.boston.com/news/education/ higher/articles/2010/06/17/reformers_blast_runaway_spending_in_college_sports/.

Zimbalist, A. (1999). Unpaid professionals: Commercialism and conflict in big-time college sports. Princeton, NJ: Princeton University Press. 